\title{
Indonesian Foreign Policy in the Era of Susilo Bambang Yudhoyono (2004-2014) towards Myanmar in Supporting Democratization
}

\author{
Windy Dermawan Chandra Purnama \& Emil Mahyudin \\ Universitas Padjajaran
}

\begin{abstract}
This research attempts to explain why Indonesia support democratization in Myanmar. In this research, researchers use constructivism perspective to analyze Indonesia's foreign policy by exploring Indonesia's reasons for promoting democratization in Myanmar. This research uses qualitative methods by collecting data through interviews with a number of informants and documentation studies. Based on the results of data analysis, this research has found that Indonesia's foreign policy toward Myanmar in supporting democratization is based on consideration of domestic, regional and global ideas, values or norms. These norms and ideas are constructed so as to encourage the formation of an Indonesian identity which is the basis for the production and reproduction of Indonesia's interests in Myanmar in promoting democratization. Indonesia's desire to re-hold regional leadership, the restoration of its image as a democratic country, and a commitment to maintain world peace are part of the production and reproduction of discourses on Indonesia's interests which contribute to the formation of Indonesia's foreign policy towards Myanmar.
\end{abstract}

Keywords: ASEAN, Democracy, Foreign Policy, Constructivism, Myanmar

Riset ini berupaya menjawab mengapa Indonesia mendukung demokratisasi di Myanmar. Dalam riset ini, peneliti menggunakan perspektif konstruktivisme untuk menganalisis kebijakan luar negeri Indonesia melalui penggalian alasan Indonesia dalam mendorong demokratisasi di Myanmar. Riset ini menggunakan metode kualitatif dengan pengumpulan data melalui wawancara terhadap sejumlah informan dan studi dokumentasi. Berdasarkan hasil analisis data, riset ini menemukan bahwa kebijakan luar negeri Indonesia terhadap Myanmar dalam mendukung demokratisasi didasari oleh pertimbangan gagasan, nilai atau norma domestik, regional, dan global. Keinginan Indonesia untuk kembali memegang kepemimpinan regional, pemulihan citra sebagai negara demokratis, dan komitmen dalam memelihara perdamaian dunia, menjadi bagian dari produksi dan reproduksi wacana mengenai kepentingan Indonesia yang turut memberikan pengaruh terhadap pembentukan kebijakan luar negeri Indonesia terhadap Myanmar.

Kata Kunci: ASEAN, Demokrasi, Kebijakan Luar Negeri, Konstruktivisme, Myanmar 


\section{Introduction}

Study about Myanmar's social and political conditions attracts the attention of scholars, especially when it is linked to domestic sociopolitical changes in the context of government transformation and democratization, and in the regional context, like security stability in relation to state and non-state actors. This research aims to analyze the non-material reasons behind the actions of a country. In this context, Indonesia's foreign policy during Susilo Bambang Yudhoyono's government towards Myanmar was reviewed through the background of the emergence of support by Indonesia. The analysis is carried out through the excavations of ideational-non-material elements in the form of ideas, values or norms, and identities that underlie Indonesia's interests in Myanmar.

Researchers conducted a study of past research that is relevant to this research. Study on democracy is interesting, especially when democracy as a part of global values becomes a foreign policy of a democratic country and is shifted to other countries (developing countries). Barany and Moser (2009) and Mcfaul (2013) reviewed that the promotion of democracy is closely related to the possibility of democratic values being exported to another country and a threat to authoritarian regimes in certain countries. Nau (2000) and Gershman (2004) stated that countries with advanced and consolidated democracies are more likely to promote their democratic values abroad, rather than newly democratic countries.

There's also a subject named economic embargo and engagement approach which can be used as a approach to assess Myanmar in promoting their democracy. Jain (2005) examined EU's approach to the military junta in Myanmar through sanctions and political and economic isolation, while Jones (2007) reviewed the role of ASEAN in supporting democratization in Myanmar through engagement policies. A review of ASEAN's role in the democratization of Myanmar was done by Acharya (2012) and Cheak (2008) who examined ASEAN's efforts through engagement aimed at exploring the reasons and achievements of ASEAN. The studies above show us about the role of regional organizations in their member countries in the context of promoting democracy.

Related to the support of democratization coming from outside the territorial boundary of a state, Archibugi (2007) and McFaul (2004) explained that the promotion of democracy acts as an instrument of persuasion of a country's foreign policy towards other countries. Sussman (2006) viewed that the promotion of democracy is a form of soft power of a country against other countries. In fact, Santos and Teixeira (2014) explained about the use of force (as a form of hard 
power) in exporting democracy, such as military intervention against Iraq and Libya. These studies above show that the issue of democratization is used as an instrument of foreign policy to cover the donor's national interest agenda in order to control and change the government regime, so that it fits the donor country's agenda.

Moreover, this research also studies about identity construction associated with a country's foreign policy. A study of non-material aspects in a country's foreign policy is discussed by Karimifard (2012) and Tidy (2012) to see the social identity of a country that provides a pattern of its foreign policy where identity is the result of construction from actors who are involved in the formation of the foreign policy. The study of Indonesia's foreign policy towards Myanmar was reviewed by Wirajuda (2014) who explained about the impact of democratization on Indonesia's foreign policy, in which democracy is a part of the policymaking process that took place in Indonesia.

The study of Indonesia's foreign policy towards Myanmar in supporting democratization through a constructive approach is still limited, so that this study aims to fill the gap in the existing research and attract other researchers to explore more deeply about the issue, especially studies on Yudhoyono's administration (2004-2014) in which democracy became an instrument and a value of Indonesia's foreign policy in its interaction with the external parties.

\section{Constructivism as the Conceptual Framework}

This paper examines Indonesia's foreign policy towards Myanmar in supporting democratization during Susilo Bambang Yudhoyono's time. The perspective used in this study is constructivism in foreign policy. Constructivism has an important position as one of the perspectives in International Relations. Its assumptions are considered relevant to explain individual state behavior in foreign policy theories.

Constructivism starts from the basic assumption that "everything is socially constructed" (Wendt 1999). The term socially means that constructivists pay attention to social factors, which is contrary to the material, in world politics. While terminology 'constructed' means that constructivists understand the world as something that is constructed through an interactive process between agents (individuals, countries, non-state actors) with a wider environmental structure. Constructivism sees that aspects of ideas are more important than material aspects. It understands that identities and interests are determined by ideas that are built, rather than what they are (Wendt 1999). In the context of this 
study, the idea of democracy promoted by Indonesia is a form of Indonesia's concern and contribution in developing democratic values.

Some concepts of constructivism that are relevant in this study include norms and power, agent relations and structure, ideas and identities, and national interests. These concepts are Indonesia's foreign policy determinants towards Myanmar. Constructivists adopt the understanding of norms into international relations as a shared hope which shared by a group of actors regarding appropriate behavior (Finnemore 1996). International Relations actors are analogous as humans who have attributes of rationality, identity, interests, beliefs, and so on (A. Wendt, 1994). Therefore, state actions are based more on consideration of good or bad and appropriate or not (the logic of appropriateness), compared to profit-loss considerations (the logic of consequences) (March \& Olsen 2009).

Constructivism also has a viewpoint at the relationship between agents and structures. Agents are political actors who have the power to do and show choices, reflexivity, knowledge, and transformation capacity (O'Neill, Balsiger, \& VanDeveer 2004), while the structure is a structured environment where the agent acts. The structure is determined by norms and identities that can be ascertained along with their material capacity and institutions (Flockhart 2006). According to constructivists, agents and structures are mutually constituted (Wendt 1999; Wendt 1987b). Constructivism has the most comprehensive perspective on the role of ideas and identities in foreign policy. Some claim that identity informs interest (Ruggie 1997), while others argue that interest requires identity (Wendt 1999). Certain norms or values that have been generally accepted and proven over a period of time will form state identity (Carlsnaes, Risse, \& Simmons 2002; Wendt, 1994). Ashizawa (2008) argues that the conception of state identity gives particular value to policymakers. First, Ashizawa stated that identity is a concept held firmly by policymakers. The second factor concerns the relationship between identity and value. Ashizawa (2008) defined values as attitudes to support certain actions; where one action is equated with a country's foreign policy. The third factor involves the relationship between value and preference, that according to Ashizawa (2008), values, which are considered by foreign policy makers, bring them to certain preferences in their country's foreign policy.

Identity can be understood through two meanings. The first one is understood by the influence of an actor on another actor in looking at himself and outside himself. It cannot be understood without being accompanied by an understanding of the wider social context in which the actor is located (Ellemers, Spears, \& Doosje 2002). Second, identity as a 'personal' category, where identity is not tied to interactions with other countries (Guzzini \& Leander 2006). Foreign policy is a 
consequence of the interaction between personal identity (domestic level) and social identity (international/systemic level).

Related to the concept of ideas, Goldstein and Keohane (1993) suggested that actions carried out by humans depend on the quality of existing ideas substantively. Ideas are useful as roadmaps and focal points in influencing foreign policy behavior. Ideas are subjective claims about world descriptions, causal relationships, or normative legitimacy of certain actions (Parsons, 2002). In relation to policy making, ideas can determine behavior after being accepted by most decision-makers (Rousseau \& Garcia-retamero 2007). The next concept is interest. Constructivism sees interest as a derivation of identity and norms. National interests as a product of interpretation of the international context (Weldes 1996) and it is given some meanings in the context of norms recognized by the international community and some understandings of what is good and appropriate to do (Finnemore 1996).

Some studies also use the concept of democracy, to be further developed in explaining democratization and democratic transitions, which is used as an analytical framework in this article. Democracy is a government characterized by accountability, competitiveness, fairness, honest elections, protection of civil and political rights, and independent civil associations (Potter 1997). In relation to the process of formulating foreign policy, for most democratic countries, the effort to project certain ideas abroad is a way to increase their international influence and this is often a characteristic of their foreign policy initiatives (Nau 2000). This idea is commonly general, though not limited to democracy and the promotion of democratic ideals (see Nau in Cox et al., 2000; Gershman 2004). In countries that promote certain ideas, preferences and strategies have become the norm for decision makers who regulate foreign policy (Wolff \& Wurm 2011).

Democratization must include changes in the structure of government, in which it was previously authoritarian, and shall enhance the accountability of rulers to the people, which previously did not exist (O'Donnell, Schmitter, \& Whitehead 1986). O'Donnell and Schmitter (1986) defined transition as a political transition where on the one hand, there is an attempt to end authoritarian regimes; on the other hand, it signals establishment of a democratic regime. The transition to democracy is not a purely political process, but a process that demands social and economic change (Nun 1993). 


\section{Ideas and Norms in Indonesian Foreign Policy towards Myanmar}

Indonesian Foreign Policy is a free and active foreign policy (bebas dan aktif). However, every period of government has its own characteristics in translating the 'Free and Active' foreign policy doctrine, including during Yudhoyono era in two periods of leadership (2004-2009 and 2009-2014). The most noticeable characteristic was Yudhoyono's ideas, "All-direction Foreign Policy", "A Million Friends, Zero Enemies" and "Dynamic Equilibrium". The three ideas above were used as the basic attitude for Indonesia to take action at the democratization issue at Myanmar.

The idea of "all direction foreign policy" doesn't mean agreeing with all parties. Indonesia's constructive policy in promoting democratization in Myanmar was a form of Indonesia's critical efforts, without having to isolate Myanmar, as it did by Western countries. One of Indonesia's constructive actions towards Myanmar in supporting democratization in the country was involving Myanmar to become a participant in the Bali Democracy Forum. In their interaction with other countries and in the process of supporting peace, the idea of "Million Friends Zero Enemy" wanted to show that Indonesia can collaborate with any values, even if the country is considered to be a binary opposition.

In addition to the ideas, regional and global norms also played an important role in shaping Indonesia's foreign policy towards Myanmar. Regional norms which emerged and became a foothold in the formulation of Indonesia's foreign policy towards Myanmar are comprised as the ASEAN Way. This term refers to a set of guidelines that been established and an unwritten code of conduct for international relations behavior, which is informally bound and respected by the member states. In carrying out regional relations and cooperation in Southeast Asia, ASEAN countries were bound to the values and norms stated in the basic principles of ASEAN, the ASEAN Way (Heiduk 2016).

Based on constructivist idea, ASEAN Way is a product of the logic of appropriateness that is mutually agreed upon so as to produce a common understanding and become a norm for ASEAN member. ASEAN Way includes behavioral norms that are packaged in a code of ethics and a set of procedural norms, as a process characterized by informality (Nischalke 2000). There are four elements of ASEAN Way: (1) the principle of non-interference; (2) quiet diplomacy; (3) noviolence in solving problems; and (4) decision making by consensus (Katsumata 2003). ASEAN values or norms as structural norms at the regional level influence the formation of Indonesia's foreign policy pattern towards Myanmar. 
Furthermore, agent-structural relations between ASEAN member countries and the global system structure also occur. Non-interference norms which applied in ASEAN experience a normative shift as a result of interaction with prevailing norms at the global level. This normative shift can be seen in the reinterpretation of non-interference and engagement norms in ASEAN. Other political developments concerning global values or norms that influenced the shift in values or norms in the region were related to the concept of Responsibility to Protect (R2P)1. The non-interference norms applicable in ASEAN are no longer relevant when there are ASEAN member countries that are unable to protect their citizens from threats to human values. In the case of Myanmar, the obligations of other member countries are helping to protect Myanmar's citizens whose human values are threatened by both state and non-state actors. The existence of regional norms should be adjusted based on the development of global norms, in which $\mathrm{R} 2 \mathrm{P}$ rose as a prominent issue and concern.

Other global norms that surfaced and provided a normative shift towards regional norms are democracy and human rights. The leaders of ASEAN countries said that discussions about the issue of democracy and human rights were unexpected and too early. In the democratic process in Myanmar, Indonesia tried to invite dialogue with Military Junta, though this attempt is viewed as a taboo by several other member countries, as it was related to the country's internal problems. However, along with political developments in the region with the signing of the ASEAN Charter, Indonesia was increasingly brave to push for a democratic transition in Myanmar. Indonesian Foreign Minister, Nurhassan Wirajuda, at that time said that to solve the problem in Myanmar, it had to be dealt with openly. He termed it as "take the bull by the horns", which refers to resolve the problem boldly.

ASEAN member countries didn't have to resolve the Myanmar issue secretly, rhetorically, and closely, particularly with this alarming human right violations and development of democratization that need to be harmonized with regional and international norms. Hence, it was necessary to ask for Myanmar's commitment to democratize its country. It was not surprising that Indonesia tried to encourage democracy through three approaches: bilateral, regional (ASEAN) and multilateral (UN).

\footnotetext{
${ }^{1}$ The concept of R2P stated that, 1) state sovereignty contains a primary responsibility to protect its citizens within the country's sovereignty; 2) when a population is in danger as a result of internal war, insurgency, repression or state failure, and the country is unwilling or Unable to stop or prevent it, the principle of noninterference justifies the international responsibility to protect. (See the International Commission on Intervention and State Sovereignty, the Responsibility to Protect, www.iciss.ca/report-en.asp.)
} 


\section{Identity as the Foundation of Indonesian Foreign Policy towards Myanmar}

Indonesia's foreign policy in supporting democratization in Myanmar was closely related to Indonesia's identity. This identity was the basis formation of Indonesia's interests and foreign policy towards Myanmar. Myanmar and Indonesia are two countries with similarities as an archipelagic country and culturally and ethnically diverse. These similarities became a code of conduct to encourage Indonesia in pursuing a dialogue with Myanmar regarding the management of this diversity within the framework of democracy.

Previous studies also analyzed several forms of social identity that became formulations for Indonesia in determining its actions toward Myanmar, including role identity and collective identity. Role identity that built Indonesia's foreign policy towards Myanmar in supporting democratization was shaped by the expectations of other actors towards Indonesia. Indonesia is considered as the third largest democratic country in the world after the United States and India and 'leaders' in ASEAN; hence, it is expected by both ASEAN and extra-regional actors to play a role in bridging Myanmar with extra-regional countries or international organizations in the process of political transition and democratization. This identification was born through interaction with other actors, both at regional and international levels.

The collective identity is simply interpreted by similarities of thoughts and feelings among ASEAN member countries. Indonesia is bound by ASEAN within a collective identity that unites its member countries. The collective identity that encourages Indonesia to support democratization in Myanmar is related to Indonesia's position in the regional sphere as a part of solidarity of ASEAN countries. Politically, Myanmar needed recognition from the international community to legitimize its military junta government. By joining ASEAN, Myanmar felt its country had a security umbrella to protect itself from international threats, including various criticisms and embargoes carried out, such as the United States and the European Union (which imposed an economic embargo on Myanmar).

\section{Indonesia's interest towards Myanmar: a milestone for regional democratization}

The democratization agenda in Myanmar cannot be separated from efforts to advance the democratization agenda in the region. Indonesia as the initiator of the democratization agenda and the promotion of human rights in the region tries to raise democracy issue in Myanmar at 
the regional level. The problems of democracy and human rights in Myanmar are clearly urgent, so that both Indonesia and ASEAN shall immediately mobilize their resources to anticipate and deal with the problem.

The defining moment is questionable when Myanmar experienced internal conflicts several times, in the form of ethnic conflicts which impact on security stability in Southeast Asia. The internal conflict in Myanmar has attracted the attention of the international community, particularly regarding human rights enforcement. The defining moment of Myanmar's human right violation issue was used as the initial basis for Indonesia to open discussions or dialogues in the context of political transition in the country without having to isolate or embargo Myanmar, which arguably may cause the country to get worse. Indonesia wanted to develop democracy in Myanmar through a political transition process, albeit its sensitivity and multidimensional nature.

\section{Constructive interaction on the agenda for democratization}

In the regional context, Indonesia's efforts to promote democratization in Myanmar are carried out through ASEAN. In fact, the agenda of promoting democracy and human rights enforcement is not only an issue for Myanmar, but also an agenda for regional stability and regional cooperation. Indonesia's starting point in bringing the idea of democracy to the region and optimization in promoting democratization in Myanmar could be seen when Indonesia became the chair of ASEAN in 2003. A number of ideas were developed as an effort to encourage Myanmar's political transition toward a democratic direction by creating a conducive climate for democratization in the region.

It reminds us about the concept of agents and structures in constructivism, which form each other (mutually constituted) (Wendt 1987). The structure of intersubjectivity that Indonesia wants to form (as an agent) is a shared understanding as a result of meetings and exchanges of ideas between individuals regarding values, norms, identities, and interests. A common understanding of the importance of democratic development, both at the national and regional levels, acts as an adhesive in cooperation and integration within ASEAN community. In another sense, the interaction between agents and structures create mutual relationship. In this case, the agent is represented by state actors and the structures are represented by regional organizations (ASEAN). When democratic climate in the region (ASEAN) is created, it is expected to have an influence on democratic climate in each member country, and vice versa. Agents may have an influence on the structure and structure influences agent preferences. 
Based on historical aspects and domestic political conditions, Indonesia prefers to play an active and central role in ASEAN. During Yudhoyono's era with his Foreign Minister, Nur Hassan Wirajuda (2001-2009) and Marty Natalegawa (2009-2014), Indonesia aspired to re-strengthen its regional leadership in ASEAN. Indonesia's foreign policy under Yudhoyono echoed the values of cooperation and peace. As foreign policy priority was based on geographical proximity, Indonesia placed ASEAN within its innermost foreign policy circle; while the second circle was East Asia and the last one was the Asia Pacific region (Anwar 2013).

In a broader political context, this effort was carried out by Indonesia by playing its role as a mediator, conflict manager among ASEAN member countries, and architect of ASEAN institution and norms. Indonesia's ambition was based on a shared belief in the importance of maintaining regional stability and security and managing conflict peacefully, which are the prerequisites for national development and prosperity (Heiduk 2016).

At the effort to welcome socialization and strengthen the understanding of democracy and the promotion of human rights, Indonesia established the Institute for Peace and Democracy (IPD) in 2009. Politically, the establishment of IPD and the implementation of BDF displayed high level of commitment and concern from Indonesia towards the promotion of democracy in the region. It reaffirmed Indonesia's efforts to restore its image as the third largest democratic country after the US and India. This commitment also confirmed Indonesia's regional leadership in the region which made democratic values as the basis of its foreign policy in the region. Through this institution, Indonesia organized Bali Democracy Forum, which did not only include countries in Southeast Asia, but also other countries in Asia-Pacific. In the context of democratization in Myanmar, IPD collaborated with a number of partner organizations in Myanmar, such as the Myanmar Peace Center and the Myanmar Development Resource Institute, to share experiences from the practices of democratization in Indonesia (Ichihara, Sahoo, \& Erawan 2016).

\section{Reflections on Indonesian interests in Region}

Indonesia's concerns to encourage democratization in Myanmar were not in the sense of interference on internal affairs of Myanmar, which violated the ASEAN Way. Indonesia still tried to engage Myanmar and encourage it to initiate democratization inside. The issue of Myanmar also attracted extra-regional power which consisted of a number of ASEAN partner countries and major countries that had good interests in Myanmar and Southeast Asia. Indonesia, as a country that initiated the 
architecture of ASEAN's political and security cooperation, had an interest in balancing multiple extra-regional powers which were present in the region. Indonesia considered that their presence could be used as a momentum to increase cooperation between ASEAN and other countries; while avoiding the threat of domination from a particular force in Southeast Asia which could possibly disrupt regional stability.

Myanmar was running on a steep line, trying to prevent China and the US from violating an agreement between them regarding their interests in Myanmar. In the context of the dilemma between the two great powers, Indonesia played its role as a dialogue partner and even a close friend of Myanmar who got huge pressure over the presence of two major powers on its country. ASEAN was expected to be the right protector for Myanmar, so that the country did not seek support or side with one particular country. Therefore, Indonesia played an active role in strengthening the intensity of dialogue with Myanmar, both bilaterally and multilaterally.

Indonesia's foreign policy has never been in favor of a hostile force. This policy emphasizes that it does not want to be trapped in competition between China and the US. Thus, it was in the interest of Indonesia to respond to the presence of extra-regional powers in Southeast Asia in the Myanmar issue, hoping that the environment in Southeast Asia could be free from any dominating force that had the potential to disrupt democracy development in Myanmar and regional security stability.

\section{Conclusion}

To find out the reasons for Indonesia's foreign policy towards Myanmar in supporting democratization, we can examine ideas, norms, and identities that shape Indonesia's interests in democratization in Myanmar. Ideas, norms, and identities are formed through the process of social interaction between Indonesia and its surroundings. This interaction forms a common understanding of what is appropriate, so that the formation of interests is not something that is given and permanent, but a dynamic process as a result of the production and reproduction of existing discourses. Ideas, values, or norms are the foundation for Indonesia to determine its identity in a social context. This identity determines Indonesia's actions in choosing its preferences through foreign policy. Identity is not given, but it is realized as a result of social construction between Indonesia and the structure of regional or international systems to produce mutual understanding.

Indonesia's foreign policy towards Myanmar is the result of the production and reproduction of discourse that develops on Indonesian ideas, values or norms, identity, and interests. These components are interrelated during an interaction between the state and its 
surroundings. Democratic norms or values in this research are used as some basis that guide Indonesia's actions, as well as tools to understand the stages in a democratic transition in Myanmar.

\section{References}

\section{Book and Chapters in Book}

Barany, Z., \& Moser, R. G. 2009. Is Democracy Exportable? New York: Cambridge University Press.

Carlsnaes, W., Risse, T., \& Simmons, B. A. (eds.). 2002. Handbook of International Relations (second). London: SAGE Publications Ltd.

Finnemore, M. 1996. National Interests in International Society. Ithaca; London: Cornell University Press.

Guzzini, S., \& Leander, A. (Eds.). 2006. Constructivism and international relations: Alexander Wendt and his critics. London and New York: Routledge.

March, J. G., \& Olsen, J. P. 2009. "The Logic of Appropriateness", in Goodin, Robert E., Michael Moran, and Martin Rein (ed.). 2009. The Oxford Handbook of Public Policy. Oxford: Oxford University Press.

Nau, H. 2000. "American Democracy Promotion: Impulses, Strategies, and Impacts”, in Cox, M., J. Ikenberry, \& T. Inoguchi (ed.). 2009. American Democracy Promotion: Impulses, Strategies, and Impacts. Oxford University Press.

O’Donnell, G. A., Schmitter, P. C., \& Whitehead, L. (ed.). 1986. Transitions from Authoritarian Rule: Prospects for Democracy. Baltimore and London: The Johns Hopkins University Press.

Potter, D. 1997. Democratization. Cambridge, Malden: Polity Press in association with the Open University.

\section{Journal and Online Journal}

Archibugi, D. 2007. "Exporting Democracy: What Have We Learned from Iraq?" Dissent, 54 (2): 40-42.

Ellemers, N., Spears, R., \& Doosje, B. 2002. "Self and Social Indentity", Group, 53 (1): 161-186.

Flockhart, T. 2006. "Complex socialization: A framework for the study of state socialization", European Journal of International Relations, 12 (1): 89-118.

Gershman, C. 2004. "Democracy promotion: The relationship of political parties and civil society.” Democratization, 11: (3): 2735 .

Jain, R. K. 2005. "India, The European Union and Asian Region.” AsiaPacific Journal of EU Studies, 3 (1): 29-44 [online] 
http://keusa.or.kr/korean/kor_publication/APJournal/2005_N 03/Eu-3-3 Rajendra K Jain.pdf

Jones, L. 2007. “ASEAN's Albatross : Burma , ASEAN' s 'Image' and the Emergence of a 'Regional Interest', Asian Security, 302 (September): 12-15.

Karimifard, H. 2012. "Constructivism, national identity and foreign policy of the Islamic Republic of Iran", Asian Social Science, (2): 239-246.

Katsumata, H. 2003. "Reconstruction of Diplomatic Norms in Southeast Asia: The Case for Strict Adherence to the ASEAN Way", Contemporary Southeast Asia: A Journal of International \& Strategic Affairs, 25 (1): 104.

Mcfaul, M. 2004. "Democracy Promotion as a World Value Democracy Promotion as a World Value", 28 (1): 147-163.

Nischalke, T. I. 2000. "Insights from ASEAN's Foreign Policy Co operation: The "ASEAN Way", a Real Spirit or a Phantom?" Contemporary Southeast Asia, 22 (1): 89-112.

Nun, J. 1993. "Democracy and Modernization, Thirty Years Later." Latin American Perspectives, 20 (79): 7-27.

O’Neill, K., Balsiger, J., \& VanDeveer, S. D. 2004. “Actors, Norms and Impact: Recent International Cooperation Theory and the Influence of the Agent-Structure Debate", Annual Review of Political Science, 7 (1): 149-175.

Parsons, C. 2002. "Showing ideas as causes: The origins of the European Union", International Organization, 56 (1): 47-84.

Rousseau, D. L., \& Garcia-retamero, R. 2007. "Identity , Power , and Threat Perception: A Cross-National Experimental Study", Journal of Conflict Resolution, 51 (5): 744-771.

Smith, E. 2000. "Estranged Bedfellows" Texas Monthly, 28 (4): 19. [online]

http://search.epnet.com/login.aspx?direct=true\&db=aph\&an=2 910609

Tidy, J. 2012. "The social construction of identity: Israeli foreign policy and the 2006 war in Lebanon." Global Society, 26 (4): 535-556.

Weldes, J. 1996. "Constructing national interests." European Journal of International Relations, 2: (3): 275-318.

Wendt, A. 1994. "State the International and Formation Identity Collective." The American Political Science Review, 88 (2): 384396.

Wendt, A. E. 1987. "The agent-structure problem in international relations theory." International Organization, 41 (3): 335-370.

Wolff, J., \& Wurm, I. 2011. "Towards a theory of external democracy promotion: A proposal for theoretical classification", Security Dialogue, 42 (1): 77-96. 


\section{Online Article}

Acharya, A. 2012. "ASEAN and Burma/Myanmar: Past and Prologue. Sigur Center for Asian Studies" [online] https://www.risingpowersinitiative.org/publication/asean-andburmamyanmar-past-and-prologue/

Cheak, P. S. F. 2008). "ASEAN'S CONSTRUCTIVE ENGAGEMENT POLICY TOWARD MYANMAR (BURMA)" [online] http://www.dtic.mil/dtic/tr/fulltext/u2/a483273.pdf

Santos, M. H. de C., \& Teixeira, U. T. 2014. "Is It Possible to Export Democracy by the Use of Force? Military Interventions in Iraq and Libya" [online] http://web.isanet.org/Web/Conferences/FLACSOISA BuenosAires 2014/Archive/db7cec23-2co5-4335-997058935298e125.pdf

Sussman, G. 2006. "The Myths of 'Democracy Assistance': U.S. Political Intervention in Post-Soviet Eastern Europe", Monthly Review An Independent Socialist Magazine [online] https://monthlyreview.org/2006/12/o1/the-myths-of-democracyassistance-u-s-political-intervention-in-post-soviet-eastern-europe/

Wirajuda, M. H. 2014. “The Impact of Democratisation on Indonesia's Foreign Policy: Regional Cooperation, Promotion of Political Values, and Conflict Management”, London School of Economic and Political Science

[online] http://etheses.lse.ac.uk/992/1/Wirajuda_Impact_of_Democratisat ion_on_Indonesias_Foreign_Policy.pdf 